\title{
Digestibility, protein retention rate and ammonia excretion in juvenile fat snook (Centropomus parallelus) fed with different protein levels
}

\section{Maria Araci Grapiuna de Carvalho ${ }^{1}$ Luiz Fernando Loureiro Fernandes ${ }^{2}$ Levy de Carvalho Gomes $^{1 *}$}

'Universidade Vila Velha (UVV), 29102-770, Vila Velha, ES, Brasil. E-mail: levy.gomes@uvv.br. "Corresponding author.

${ }^{2}$ Universidade Federal do Espírito Santo (UFES), Vitória, ES, Brasil.

ABSTRACT: The aim of this study was to determine the level of dietary crude protein (CP) (480, 400, 440, 520 and $\left.560 \mathrm{~g} \mathrm{~kg}^{-1}\right)$ in rations for juvenile II fat snook (Centropomus parallelus) that best promotes protein absorption and lower excretion of nitrogenous products. Three experiments were conducted: the first assessed the protein retention rate; the second evaluated ammonia excretion; and the third determined the best digestibility coefficient. The estimated protein retention rate showed a positive quadratic response to dietary CP with maximum retention at the $510.20 \mathrm{~g} \mathrm{~kg}^{-1}$ protein level, and increasing levels of protein resulted in a greater total ammonia excretion rate in water. The mean apparent protein digestibility coefficient values increased with increasing levels of dietary protein up to $520 \mathrm{~g} \mathrm{~kg}^{-1}$, where they stabilized. As determined by regression, the level of dietary CP that promotes the best digestibility was $495.62 \mathrm{~g} \mathrm{~kg}^{-1}$.

Key words: crude digestible protein, fish culture, nitrogen excretion, diet.

Digestibilidade, taxa de retenção proteica e excreção de amônia em juvenis de robalo-peva (Centropomus parallelus) alimentados com rações com diferentes níveis de proteína

RESUMO: O objetivo da pesquisa foi determinar o nível de proteína bruta na dieta (400, 440, 480, 520 e 560g $\left.\mathrm{kg}^{-1}\right)$, nas rações de juvenis II de robalo-peva (Centropomus parallelus), que promove melhor absorção de proteína e menor excreção de produtos nitrogenados. Foram realizados três experimentos. O primeiro avaliou a taxa de retenção de proteína, o segundo a excreção de amônia, e o terceiro determinou o melhor coeficiente de digestibilidade. Os dados foram analisados por meio de regressão exponencial. A taxa de retenção proteica, calculada pela equação, apresentou efeito quadrático positivo e o máximo de retenção com $510,20 \mathrm{~g} \mathrm{~kg}^{-1}$ de proteína na dieta. O aumento dos níveis de proteína resultou em maiores taxas de excreção de amônia total na água. Os valores médios dos coeficientes de digestibilidade aparente da proteína foram aumentando com o aumento da proteína dietética até o nível de $520 \mathrm{~g} \mathrm{~kg}^{-1}$ onde se estabilizou. O nivel de proteina bruta na dieta, determinado pela equação de regressão, que promove a melhor digestibilidade é de 495,62 $\mathrm{kg}^{-1}$.

Palavras-chave: proteína bruta digestível, piscicultura, excreção nitrogenada, dieta.

\section{INTRODUCTION}

Centropomus parallelus (fat snook) is a marine fish that is highly valued for its meat, which has excellent organoleptic qualities and is low in fat and calories, rich in polyunsaturated fatty acids and white in color. However, despite its high value in domestic and foreign markets, the species has been threatened by predatory fishing and anthropogenic impacts (DUTKAGIANELLI, 2010). For commercial breeding to become a reality, several types of scientific information are needed, including data on animal nutrition.

In animal nutrition, evaluation of feed digestibility coefficient is important to maximize nutrient utilization, reduce production costs and minimize water pollution by reducing the amount of nitrogen, phosphorus and organic matter that is eliminated (CANESIN et al. 2012). Digestibility, i.e., the ability of an animal to digest and absorb the nutrients contained in the diet, is one of the criteria used to quantify the diets nutrient utilization efficiency (BERCHIELLI et al., 2011; POND et al., 2005).

Protein is one of the most important nutrients in fish diets due to its role in growth, maintenance and reproduction as well as being an important source of energy (MARTÍNEZ-PALÁCIOS et al., 2007), so it should be included at adequate levels in the diet to ensure good protein efficiency (CARVALHO et al., 2010). When included in excess, protein results in increased ammonia excretion (SÁ et al., 2008), leading to environmental damage. The protein level in carnivorous fish diets fish should be 
approximately 40 to $50 \%$ (DENG et al., 2006), and in the case of fat snook, SOUZA et al. (2011) suggested levels greater than $50 \%$.

Determining the optimum dietary protein for fish enables the formulation of diets that maximize protein retention and reduce nitrogen excretion, thus reducing the costs and environmental impacts of aquaculture (CYRINO et al., 2010, WEBB et al., 2010, AHMED \& KHAN, 2004). Therefore, the objective of this study was to determine the level of protein in juvenile II fat nook rations that would lead to a better apparent digestibility coefficient (ADC), greater protein retention and lower ammonia excretion.

\section{MATERIALS AND METHODS}

Diets with different protein levels (400, 440, 480, 520 and $560 \mathrm{~g} \mathrm{~kg}^{-1}$ ) were tested in three experiments with completely randomized designs consisting of five treatments and four replicates (20 experimental units).

Rations were produced in a commercial feed mill, and the same ingredients were used in each (Table 1). Rations were extruded, isocaloric and isolipidic and had the same premix formulation and pellet diameter $(2.5 \mathrm{~mm})$. Titanium dioxide was used as the external indicator and was added as $1 \%$ of the diets (TITGEMEYER et al., 2001).

\section{Experiment 1: Protein Retention Rate}

A total of 200 juvenile fat nook $(27.02 \pm 0.27 \mathrm{~g})$ were randomly distributed into 20 $500-\mathrm{L}$ polyethylene tanks (density of $0.7 \mathrm{~g} \mathrm{~L}^{-1}$ ) that were maintained with filtered and sterilized sea water, constant aeration with compressors and a temperature of $28^{\circ} \mathrm{C}$ that was controlled by a $400 \mathrm{~W}$ thermostat; $50 \%$ of the tank water volume was renewed daily. The mean water quality parameter values were as follows: temperature $\left(27.2 \pm 1.2^{\circ} \mathrm{C}\right)$, dissolved oxygen $\left(8.4 \pm 0.33 \mathrm{mg} \mathrm{L}^{-1}\right)$, salinity $(32.3 \pm 1.1 \mathrm{ppt}), \mathrm{pH}(7.53 \pm 0.5)$ and total ammonia $\left(0.24 \pm 0.04 \mathrm{mg} \mathrm{L}^{-1}\right)$. Each day for 60 days, fish were fed at $2 \%$ of their total biomass, which was divided into two meals ( $8 \mathrm{am}$ and $4 \mathrm{pm}$ ).

At the beginning and end of the experiment, $100 \%$ of the fish were fasted for $24 \mathrm{~h}$ and then anesthetized with benzocaine $\left(50 \mathrm{mg} \mathrm{L}^{-1}\right)$ for biometric analysis. Body tissues of a sample of four animals per replicate were analyzed, and these fish were euthanized by benzocaine overdose (200mg $\mathrm{L}^{-1}$ ) and frozen for subsequent protein quantification according to the method described by the Association of Official Analytical Chemists (AOAC, 2000). The apparent protein retention rate (APRR) was calculated using the formula: APRR $(\%)=[(\mathrm{Wf} \times \mathrm{BPf})-(\mathrm{Wi} x$ $\mathrm{BPi})$ / TPC] x 100, where Wf = final weight; BPf = final body protein; $\mathrm{Wi}=$ initial weight; $\mathrm{BPi}=$ initial body protein; TPC $=$ total protein consumption.

\section{Experiment 2: Ammonia Excretion}

Following the first experiment, nine juvenile fat snook $(38.28 \pm 1.07 \mathrm{~g})$ remained in each of the 20 experimental tanks for one week for adaptation, and the water volume was adjusted so that each tank maintained a density of $2 \mathrm{~g} \mathrm{~L}^{-1}$. As above, the seawater for tanks was filtered and sterilized; 50\% of its volume was changed daily; and aeration was performed using compressors.

After the adaptation period, the fish were anesthetized with benzocaine $\left(50 \mathrm{mg} \mathrm{L}^{-1}\right)$, weighed on a precision scale $(0.01 \mathrm{~g})$, and then returned to their tank, which had been washed and filled with clean water. Fish were then fasted for $48 \mathrm{~h}$ to empty their digestive tracts. After the fasting period, $100 \%$ of the water was replaced in all of the tanks, and the animals received rations at the proportion of $1 \%$ of the biomass of their respective treatment. The excretion test lasted $48 \mathrm{~h}$, and water was collected from each tank at the beginning and at the end of the experiment. The mean values of the physical water variables for the 20 tanks during the two days of the experiment were as follows: salinity $(32.91 \pm 0.05 \mathrm{ppt})$, temperature $\left(26.89 \pm 0.11^{\circ} \mathrm{C}\right)$, dissolved oxygen (5.77 $\left.\pm 0.06 \mathrm{mg} \mathrm{L}^{-1}\right)$ and $\mathrm{pH}(7.85 \pm 0.05)$. Three additional tanks were used as a positive control to evaluate the ammonia produced by bacteria; in these tanks, water was added and aeration was performed similar to the experimental tanks. Values obtained in the control tanks were subtracted from the final excretion calculation.

Analysis of the ammonia in water was performed using the indophenol method according to APHA (2005). Ammonia excretion was calculated according to ALTINOK \& GRIZZLE (2004) based on the following formula: excretion rate $=\{[(\mathrm{NHF}-$ $\mathrm{NHI} / \mathrm{g}$ total] / L , where NHF corresponds to final ammonia concentration, and NHI corresponds to the initial ammonia concentration, which was divided by the biomass and the amount of water in each tank. Amount of ammonia excreted relative to the amount of protein ingested was also calculated and the result was expressed as a percentage.

\section{Experiment 3: Apparent Protein Digestibility}

The apparent digestibility test was performed with 60 fish that were distributed into 20 fiberglass incubators with conical bottoms 
Table 1 - Composition and proximate analysis of diets $\left(\mathrm{g} \mathrm{kg}^{-1}\right)$ used with different concentrations of crude protein for fat snook.

\begin{tabular}{|c|c|c|c|c|c|}
\hline Ingredients (\%) & 400 & 440 & 480 & 520 & 560 \\
\hline Fish meal 55 & 25 & 25 & 25 & 25 & 25 \\
\hline Viscera meal 60 & 5 & 5 & 5 & 5 & 5 \\
\hline Toasted soybean meal 44 & 8.41 & 9.85 & 11.29 & 5 & 5 \\
\hline Soy protein concentrate & 5 & 5 & 5 & 5 & 5 \\
\hline Ground whole corn & 18.29 & 12.00 & 5.72 & 3.45 & 2 \\
\hline Rice bran & 9 & 9 & 9 & 9 & 9 \\
\hline Broken rice & 10 & 10 & 10 & 10 & 6.04 \\
\hline Fish oil & 2.8 & 2.9 & 3 & 3.07 & 3.05 \\
\hline Premix ${ }^{1}$ & 1 & 1 & 1 & 1 & 1 \\
\hline Wheat gluten & 2.50 & 7.25 & 11.99 & 20.48 & 25.91 \\
\hline Blood cells AP301 & 12 & 12 & 12 & 12 & 12 \\
\hline Titanium dioxide & 1 & 1 & 1 & 1 & 1 \\
\hline \multicolumn{6}{|c|}{ 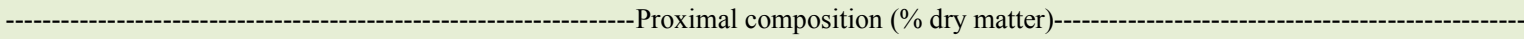 } \\
\hline Moisture & 7.65 & 7.57 & 7.76 & 9.77 & 6.63 \\
\hline Crude protein & 39.91 & 43.33 & 47.25 & 52.21 & 55.83 \\
\hline Non-nitrogenous extractive & 30.53 & 24.56 & 21.82 & 15.16 & 15.75 \\
\hline Lipid & 10.31 & 10.87 & 9.96 & 9.99 & 10.81 \\
\hline Crude fiber & 1.52 & 3.33 & 3.16 & 2.59 & 2.19 \\
\hline Mineral matter & 10.07 & 10.42 & 10.61 & 10.00 & 8.84 \\
\hline Gross energy $\left.(\mathrm{Mcal} \mathrm{kg})^{-1}\right)^{2}$ & 4.55 & 4.68 & 4.72 & 4.75 & 4.98 \\
\hline Gross energy / Crude protein ratio ( $\left.\mathrm{Mcal} \mathrm{kg}^{-1}\right)$ & 11.40 & 10.80 & 9.99 & 9.10 & 8.92 \\
\hline
\end{tabular}

${ }^{1}$ Premix is the registered trademark of Nutriave. Guaranteed levels per kilogram of feed: Vit. A: 2,000,000.00IU; Vit. D3: 500,000.00IU; Vit. E: 15,000.00IU; Vit. K3: 1,000.00mg; Vit B1: 2,500.00mg; Vit. B2: 3,000.00mg; Vit. B6: 5,000.00mg; Vit. B12: 6,250.00mg; Pantothenic acid: 3,750.00mg; Niacin: 10,000mg; Folic Acid: 1,250.00mg; Biotin: 1,250.00mg; Choline: 125,000.00mg; Selenium: 75.00mg; Copper: 3,750.00mg; Iron: 15,000.00mg; Manganese: 7,500.00mg; Iodine: 125.00mg; Zinc: 20,000.00mg; Gross energy (GE) calculated using the mean combustion energy values of nutrients $\left(5.65 \mathrm{kcal} \mathrm{g}^{-1} \mathrm{CP}, 9.40 \mathrm{kcal} \mathrm{g}^{-1}\right.$ lipid and $4.15 \mathrm{kcal} \mathrm{g}^{-1}$ of fiber and carbohydrate) (MAYNARDI \& LOOSLI, 1974).

connected to a collector tube with a quick-closing PVC valve, which was used to collect feces by decanting. Incubators had an $80-\mathrm{L}$ capacity, but only $70 \mathrm{~L}$ was used. Constant mechanical aeration was maintained through porous stones placed at a depth of $10 \mathrm{~cm}$ to prevent airflow from suspending the feces and thus promoting leaching. Three fish were randomly distributed into each incubator (density $1.4 \mathrm{~g} \mathrm{~L}^{-1}$ ) for one month for adaptation to the facilities, environment and management protocols (feeding, cleaning and incubator water exchange). Fish were fed $2 \%$ of their biomass, i.e., $1 \%$ in the morning and $1 \%$ in the afternoon.

Fecal collection period lasted two months, during which the fish were fed $1 \%$ of their biomass per day divided into two feedings ( $8 \mathrm{am}$ and $4 \mathrm{pm}$ ) to avoid leftover rations in the incubators. One hour after feeding, the incubator walls were brushed, and 90\% of the water was renewed to remove unconsumed food and fecal waste. Feces were collected twice a day (7am and $3 \mathrm{pm}$ ), transferred to a labeled jar and stored at $-10^{\circ} \mathrm{C}$ until the end of the experiment.

During the experimental period, the water quality parameters presented mean temperature, salinity, $\mathrm{pH}$ and dissolved oxygen values of $26.30 \pm 0.32^{\circ} \mathrm{C}$, $32.14 \pm 0.69 \mathrm{ppt}, 7.8 \pm 0.6$ and $5.77 \pm 0.06 \mathrm{mg} \mathrm{L}^{-1}$, respectively.

Crude protein (CP) analysis was performed using the Kjeldahl method, and the concentration of titanium in the feces and diets was determined according to the method described by MYERS et al. (2004). The ADC was calculated according to the equation of $\mathrm{CHO}$ et al. (1982): $\mathrm{ADC}=1-(\mathrm{F} / \mathrm{D} \times \mathrm{Di}$ $/ \mathrm{Fi}$ ), where $\mathrm{D}=\%$ of the nutrient in the diet; $\mathrm{F}=\%$ of the nutrient in the feces; $\mathrm{Di}=$ indicator concentration in the diet; and $\mathrm{Fi}=$ indicator concentration in the feces.

\section{Statistical analysis}

Results of the analyzed parameters were subjected to exponential regression analysis using SigmaStat 12.5. 


\section{RESULTS AND DISCUSSION}

The APRR, calculated using a quadratic regression, showed a positive effect $(\mathrm{P}<0.01$, Figure 1); with the increase in dietary protein, the APRR increased up to the level of $480 \mathrm{~g} \mathrm{~kg}^{-1}$. The highest protein retention calculated by the quadratic regression was observed with a diet with $510.20 \mathrm{~g} \mathrm{~kg}^{-1}$ of protein, and the increase in the APRR between 400 and $480 \mathrm{~g} \mathrm{~kg}^{-1}$ suggested ongoing tissue deposition. According to CARVALHO et al. (2010), it is important to include adequate levels of protein in the diet to promote good zootechnical indexes in fish and to minimize costs because, according to SOUZA et al. (2011), protein is the most expensive nutrient in diet formulations for aquatic organisms.

Increase in dietary protein levels positively and quadratically increased the rates of total ammonia excretion in water $(\mathrm{P}<0.01$; Figure $2 \mathrm{~A})$, and the excretion of total ammonia at the initial protein concentrations was smaller but increased with the last two levels. This was probably due to an excess of protein because, according to MELO et al. (2006), when protein is present in excess, its amino acids are transaminated and/or deaminated, and resulting carbon skeleton is diverted to energetic metabolic routes, resulting in increased nitrogen excretion (SÁ et al.,
2008). Increase in dietary protein (400 to $\left.560 \mathrm{~g} \mathrm{~kg}^{-1}\right)$ promoted a $62 \%$ increase in total ammonia excretion in water, demonstrating a direct relationship between protein intake and ammonia excretion in fish. Figure 2B showed that with the 400, 440, 480, 520 and $560 \mathrm{~g} \mathrm{~kg}^{-1}$ rations, the amount of ammonia excreted $(52.54 \pm 4.46,52.69 \pm 4.83,53.16 \pm 6.31,56.12 \pm 5.61$ and $58.25 \pm 8.74 \%$, respectively) by fat snook increased with mean protein intake $(1.15 \pm 0.06 \mathrm{~g}, 1.34 \pm 0.05 \mathrm{~g}$, $1.46 \pm 0.11 \mathrm{~g}, 1.62 \pm 0.02 \mathrm{~g}$ and $1.69 \pm 0.11 \mathrm{~g}$, respectively). This result is consistent with those obtained by ABDEL-TAWWAB et al. (2006) with Nile tilapia (Oreochromis niloticus), PERES \& OLIVA-TELES (2007) with European seabass (Dicentrarchus labrax) and MELO et al. (2006) with jundiá (Rhamdia quelen).

The quadratic regression equation showed that protein concentration in the diet had a positive effect on the apparent protein digestibility $(\mathrm{P}<0.01)$. The ADC was better in the rations with 520 and $560 \mathrm{~g}$ $\mathrm{kg}^{-1}$ of protein (Figure 3), and according to the quadratic equation, the level of $495.62 \mathrm{~g} \mathrm{~kg}^{-1}$ of protein in the diet provides the best ADC. Determining digestibility coefficients is an important tool in the development of diets to promote good fish nutrition and consequently obtain better responses in terms of weight gain, feed conversion and APRR as well as higher financial returns and lower environmental impacts (ONO et

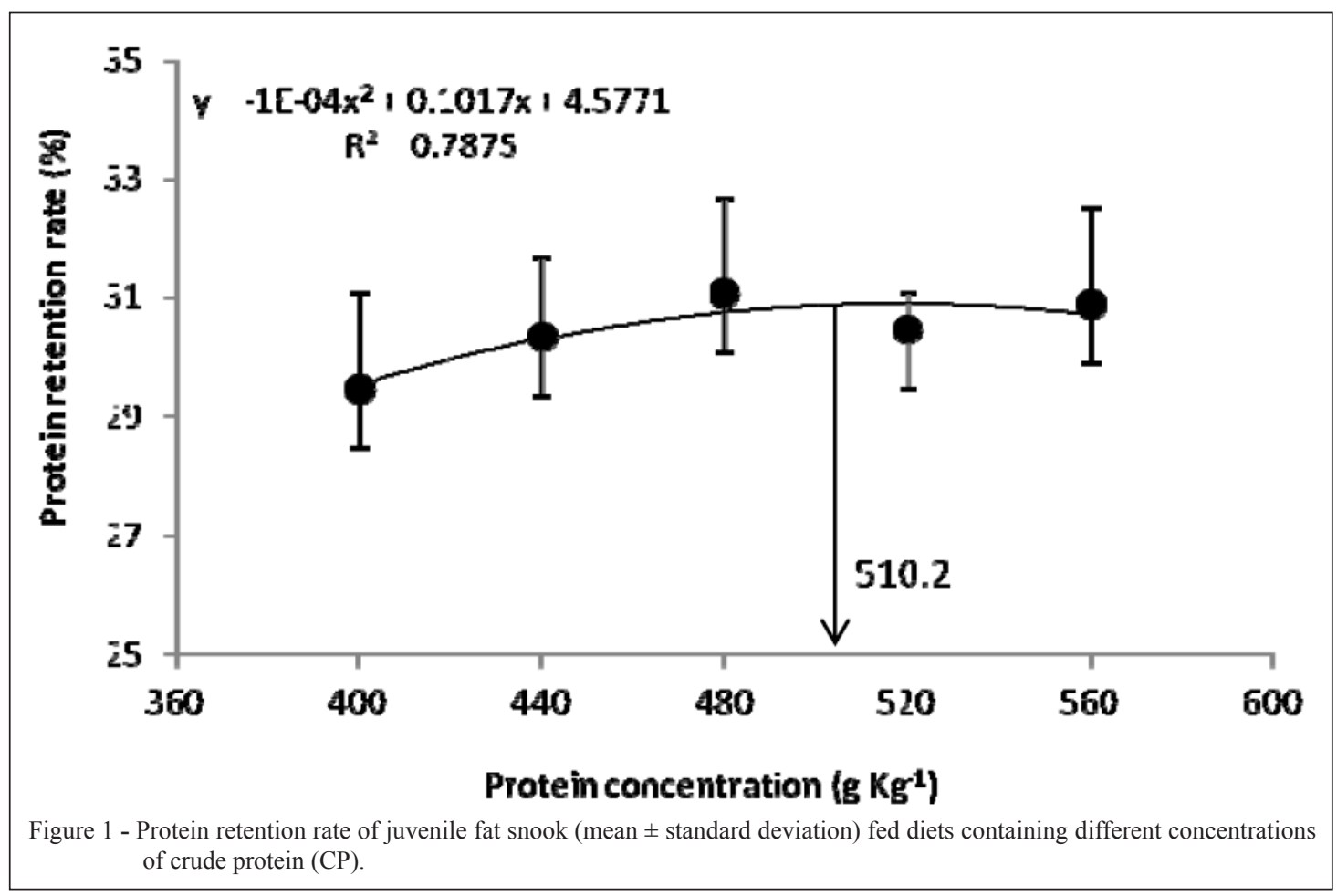

Ciência Rural, v.47, n.7, 2017. 


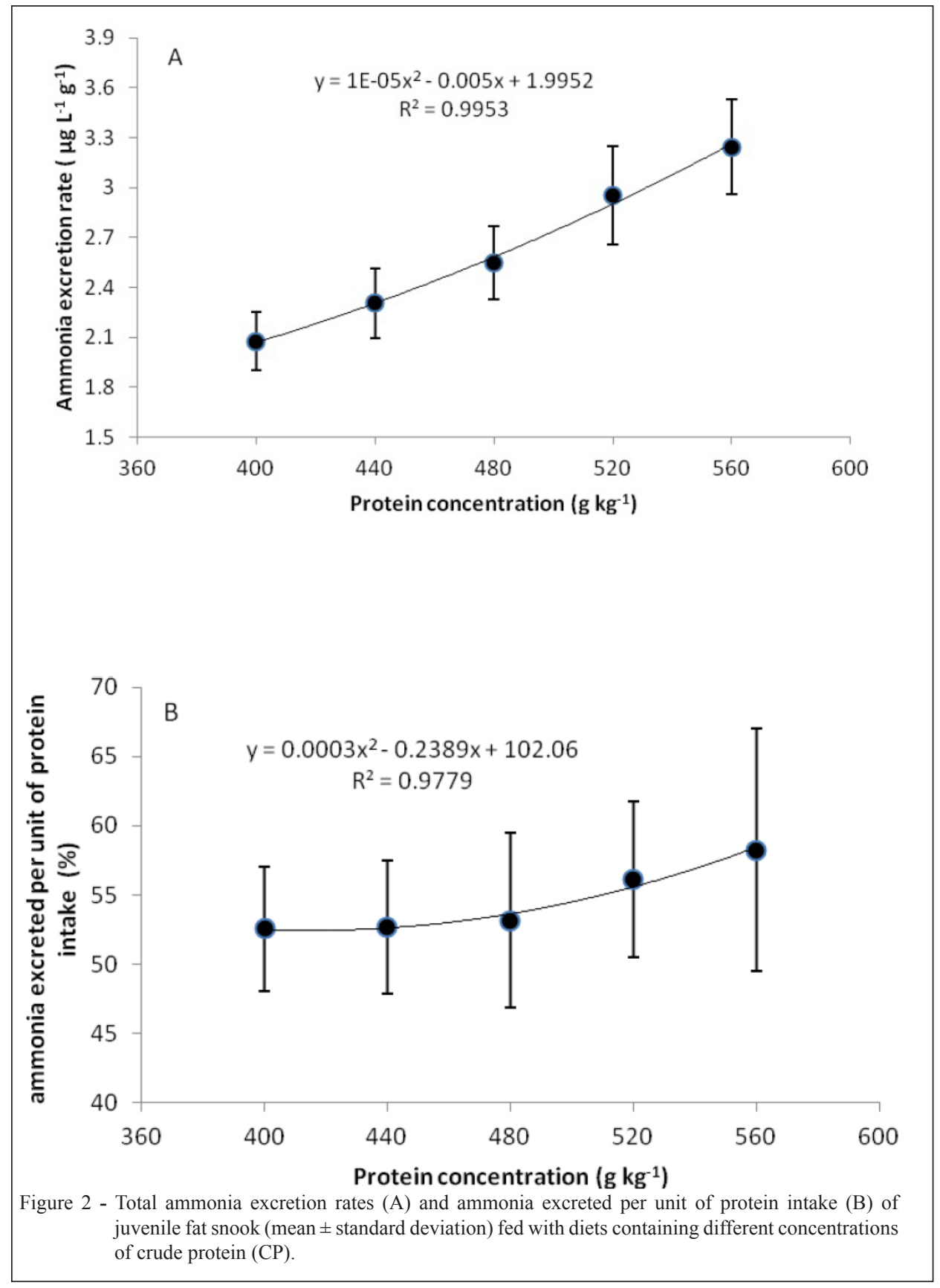

al., 2010; SAKOMURA \& ROSTAGNO, 2007). The ADC of CP varied non-linearly from 42.66 to 54.12 when protein concentration in the diet increased from 400 to $560 \mathrm{~g} \mathrm{~kg}^{-1}$, confirming the report by FURUYA et al. (2001) that increased diet digestibility is directly related to better nutrient utilization. However, according to GONÇALVES et al. (2009), one should be aware of the protein level in the diet because high levels may result in the excess being converted into energy or excreted. To avoid this possible waste, it is recommended a dietary protein concentration of $495.62 \mathrm{~g} \mathrm{~kg}^{-1}$, as this was the level determined by the regression equation that promoted the best digestibility. According to THOMAN et al. (1999), the APRR has a positive relationship with diet digestibility and protein content, among other factors, and this relationship was also observed in fat snook. The protein level that promoted higher protein 


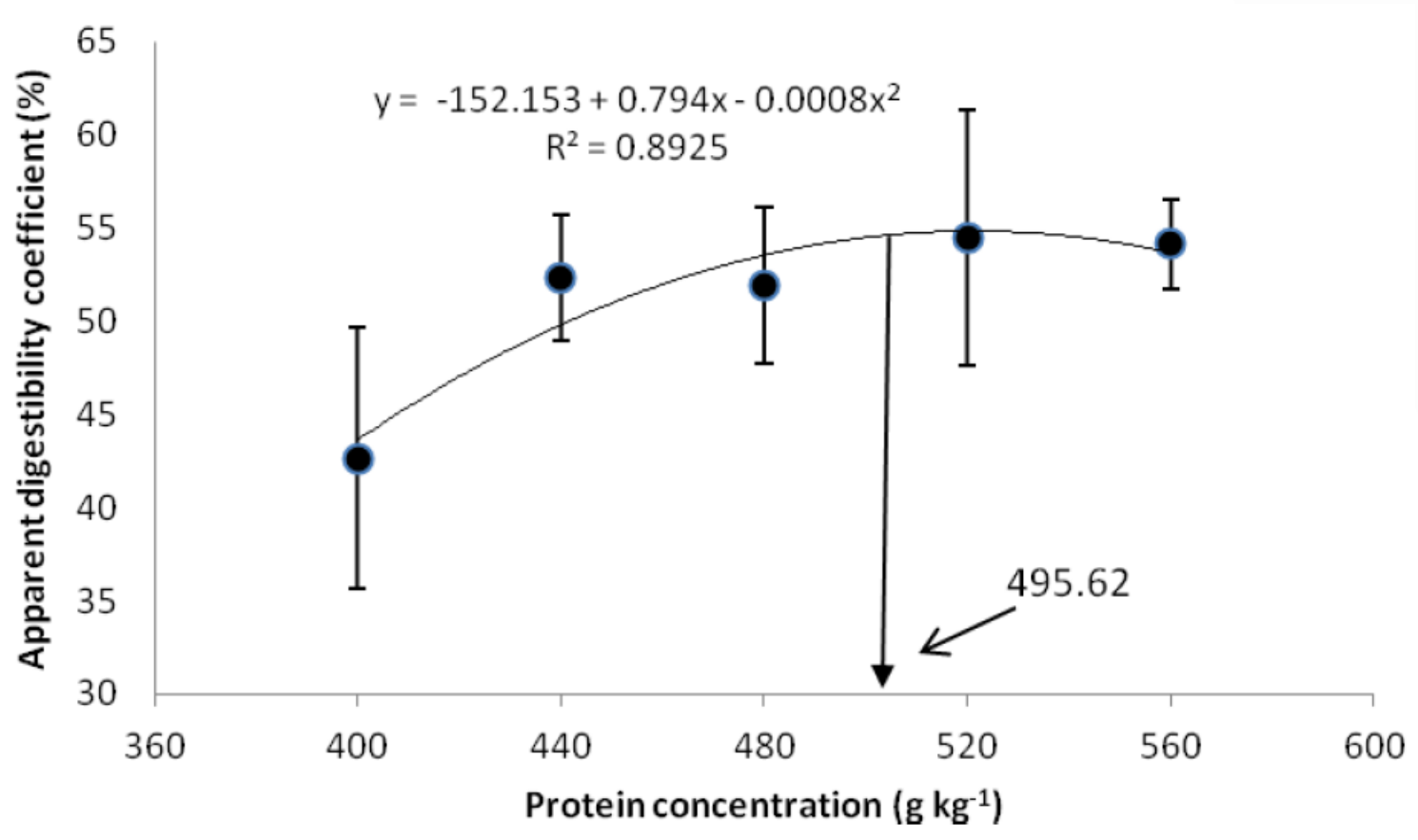

Figure 3 - Apparent digestibility coefficients of juvenile fat snook (mean \pm standard deviation) fed diets containing different concentrations of crude protein $(\mathrm{CP})$.

retention and higher digestibility was very similar between the two studies (difference of $15 \mathrm{~g} \mathrm{~kg}^{-1}$ ) and coincided with a proportional increase in ammonia excretion. These results indicated that an animal increases ammonia excretion at the same time that it decreases protein absorption. Rations with a protein level higher than $500 \mathrm{~g} \mathrm{~kg}^{-1}$ may promote greater growth and weight gain in fat snook, as observed by CARVALHO (2015), but the results obtained in the present study did not support such a high ration. This assertion is related to inefficient retention with increasing protein levels and thus had a greater potential for negative environmental impacts from the discharge of a higher concentration of ammonia Based on this study, the highest protein digestibility and absorption and the lowest relative ammonia excretion in juvenile fat snook occurred with protein concentrations between 496 and $510 \mathrm{~g} \mathrm{~kg}^{-1}$.

\section{ACKNOWLEDGEMENTS}

The authors thank the Conselho Nacional de Desenvolvimento Científico e Tecnológico (CNPq) and the Fundação de Amparo à Pesquisa e Inovação do Espírito Santo (FAPES) for financial support, the Nutriave Company for the preparation of the experimental rations and Dr. Francisco Monteiro (ESALQ) for performing the titanium dioxide analyses.

\section{BIOETHICS \\ AND \\ BIOSSECURITY COMMITTEE APPROVAL}

The study was approved by the Ethics Committee on the Use of Animals in Research of the Universidade de Vila Velha (UVV), Brazil, under permit number 307/2014.

\section{REFERENCES}

ABDEL-TAWWAB, M. et al. Effect of dietary protein level, initial body weight and their interaction on the growth, feed utilization and physiological alterations of Nile tilapia, Oreochromis niloticus (L.). Aquaculture, v.298, p.267-274, 2010. Available from: <http:// www.sciencedirect.com/science/article/pii/S0044848609008849>. Accessed: Mar. 20, 2016.

AHMED, I.; KHAN, M.A. Dietary lysine requirement of fingerling Indian major carp, Cirrhinus mrigala (Hamilton). Aquaculture, v.235, p.499-511, 2004. Available form: <http://www. sciencedirect.com/science/article/pii/S0044848603008378>. Accessed: Abr. 11, 2016.

ALTINOK, I.; GRIZZLE, J.M. Excretion of ammonia and urea by phylogenetically diverse fish species in low salinities. Aquaculture, v.238, p.499-507, 2004. Available form: <http:// www.sciencedirect.com/science/article/pii/S0044848604003709>. Accessed: Jan. 24, 2016.

ASSOCIATION OF OFFICIAL ANALYTICAL CHEMISTS (AOAC). Official methods of analysis of official analytical chemists. Arlington, 2000. 2200 p. 
BERCHIELLI, T.T. et al. Principais técnicas de avaliação aplicadas em estudo de nutrição. Jaboticabal: FUNEP, 2011. 600 p.

CANESIN, R.C. et al. Innovations and challenges in food evaluation in ruminant nutrition. Revista Brasileira de Saúde e Produção Animal, v.13, p.938-953, 2012. Available from: <http://www.scielo. br/pdf/rbspa/v13n4/09.pdf >. Accessed: June 15, 2015.

CARVALHO, M.A.G. Oferta eficiente de proteína como mitigador do impacto ambiental da criação de robalo-peva (Centropomus parallelus, POEY, 1860). 2015. 99f. Tese (Ecologia de Ecossistema) Curso de Pós-graduação em Ecologia de Ecossistemas, Universidade Vila Velha.

CARVALHO, C.V.A. et al. The effect of protein levels on growth, postprandial excretion and tryptic activity of juvenile mullet Mugil platanus (Günther). Aquaculture Research, v.41, p.511-518 2010. Available from: $<$ http://onlinelibrary.wiley.com/doi/10.1111/ j.1365-2109.2009.02340.x/epdf>. Accessed: June 10, 2015.

CYRINO, J.E.P. et al. Fish farming and the environment - the use of environmental friendly feeds in fish culture. Revista Brasileira de Zootecnia, v.39, p.68-87, 2010. Available from: $<$ http://www.scielo. br/scielo.php?script=sci_arttext\&pid=S1516-35982010001300009>. Accessed: Feb. 20, 2015.

DUTKA-GIANELLI, J. Life history and ecology of the small scale fat snook, Centropomus parallelus (Centropomidae) in East Central Florida, and methodology to identify the regional snooks species. 2010. 213f. (Tese Doutorado em Fisheries \& Aquatic Sciences) - Florida Institute of Tecnology, Melbourne.

DENG, J. et al. Effects of replacing fish meal with soy protein concentrate on feed intake and growth of juvenile Japanese flounder (Paralichthys olivaceus). Aquaculture, v.258, p.503-513, 2006. Available from: $<$ http://www.sciencedirect.com/science/article/pii/ S004484860600250X>. Accessed: Feb. 20, 2015.

GONÇALVES, G.S. et al. Level of digestible protein and digestible energy in diets for Nile tilapia formulated based on the concept of ideal protein. Revista Brasileira de Zootecnia, v.38, p.2289-2298, 2009. Available from: $<$ http://www.scielo.br/scielo.php?script=sci arttext\& pid=S1516-35982009001200001>. Accessed: Abr. 02, 2015.

MARTÍNEZ-PALACIOS, C.A. et al. Dietary protein requirement of juvenile Mexican Silverside (Menidia estor Jordan 1879), a stomachless zooplanktophagous fish. Aquaculture Nutrition, v.13, p.304-310, 2007. Available from: <http://onlinelibrary.wiley.com/doi/10.1111/ j.1365-2095.2007.00479.x/epdf>. Accessed: Abr. 20, 2016.

MAYNARD, L.A.; LOOSLI, J.K. Nutrição animal. São Paulo: F. Bastos, 1974. 550 p.

MELO, J.F.B. et al. Effects of dietary levels of protein on nitrogenous metabolism of Rhamdiaquelen (Teleostei,Pimelodidae). Comparative
Biochemistry and Physiology A, v.145, p.181-187, 2006. Available from: <https://www.researchgate.net/publication/6909601_Effects of_dietary_levels_of_protein_on_nitrogenous_metabolism_of Rhamdia_quelen_Teleostei_Pimelodidae $>$. Accessed: Mar. 20, 2016.

MYERS, W.D. et al. Technical Note: a procedure for the preparation and quantitative analysis of samples for titanium dioxide. Journal of Animal Science, v.82, p.179-183, 2004. Available from: $<$ https://www. animalsciencepublications.org/publications/jas/articles/82/1/179>. Accessed: Mar.20, 2016.

ONO, E.A. et al. Apparent digestibility coefficient of practical diets with different energy: protein ratios for pirarucu juveniles. Pesquisa Agropecuária Brasileira, v.43, p.249-254, 2008. Available from: <http:/ www.scielo.br/scielo.php?pid=S0100-204X2008000200014\&script=sci abstract\&tlng-pt>. Accessed: Feb. 20, 2015.

PERES, H.; OLIVA-TELES, A. Effect of the dietary essential amino acid pattern on growth, feed utilization and nitrogen metabolism of European sea bass (Dicentrarchus labrax). Aquaculture, v.267, p.119-128, 2007. Available from: <http://www.sciencedirect.com/ science/article/pii/S0044848607000440>. Accessed: Feb. 22, 2015.

POND, W.G. et al. Basic animal nutrition and feeding. Hoboken: Wiley, 2005. 580 p.

SÁ, R. et al. Dietary protein requirement of white sea bream (Diplodus sargus) juveniles. Aquaculture Nutrition, v.14, p.309-317, 2008. Available from: <http://onlinelibrary.wiley.com/doi/10.1111/j.13652095.2007.00532.x/epdf>. Accessed: Mar. 23, 2016.

SAKOMURA, N.K.; ROSTAGNO, H.S. Métodos de pesquisa em nutrição de monogástricos. Jaboticabal: FUNEP, 2007. 283 p.

SOUZA, J.H. et al. Growth and economic performance of juvenile fat snook fed diets containing different protein levels. PesquisaAgropecuária Brasileira, v.46, p.190-195, 2011. Available from: <http://www. scielo.br/scielo.php?pid=S0100-204X2011000200011\&script $=$ sci abstract\&tlng-pt>. Accessed: Feb. 12, 2015.

THOMAN, E.S. et al. Evaluation of grow out diets with varing protein and energy levels for red drum (Sciaenops ocellatus). Aquaculture, v.176, p.343-353, 1999. Available from: <http://www.sciencedirect.com/ science/article/pii/S0044848699001180>. Accessed: Feb. 22, 2015.

TITGEMEYER, EC e et al Evaluation of titanium dioxide as a digestibility marker for cattle. Journal of Animal Science, v.79, p.10591063, 2001. Available from: $<$ https://www.animalsciencepublications. org/publications/jas/pdfs/79/4/1059>. Accessed: Feb. 22, 2015.

WEBB JUNIOR, K.A. et al. Effects of dietary starches and the protein to energy ratio on growth and feed efficiency of juvenile cobia, Rachycentron canadum. Aquaculture Nutrition, v.16, p.447-456, 2010. Available from: <http://onlinelibrary.wiley.com/doi/10.1111/ j.1365-2095.2009.00672.x/epdf>. Accessed: Feb. 22, 2015. 